\title{
The neonatal surgical intensive care unit: a Bifocal Clinical Practice Model approach
}

Nicola Ramacciati, RN; MA, Chief Nurse, Accident and Emergency Department, S. Maria della Misercordia Hospital, Perugia, Italy Beniamino Addey, RN; BSc, Staff Nurse, Accident and Emergency Department, S. Maria della Misercordia Hospital, Perugia, Italy

Key Words: bifocal model * NANDA * neonatal intensive care unit * neonatal surgery * nursing diagnosis *

E-mail: nicola.ramacciati@ospedale.perugia.it

\section{ESPAÑOL}

La unidad de cuidado intensivo quirúrgico neonatal: un abordaje según el Modelo Bifocal de Práctica Clínica

Palabras clave

Cirugía neonatal, diagnóstico de enfermería, Modelo Bifocal, NANDA-I, unidad de cuidado intensivo neonatal

Resumen

El paciente recién nacido críticamente enfermo en la unidad de cuidado intensivo neonatal (UCIN) genera un desafío emocional duro y difícil para enfermería. La complejidad necesaria hace crucial el abordaje multidisciplinar, multiprofesional y multidimensional. Esto se debe al hecho de que la 'persona' que recibe el cuidado es en realidad una unidad compuesta por el recién nacido y sus padres; por tanto requiere una mirada holística ampliada que englobe tanto las necesidades expresadas y no expresadas de la familia.

La respuesta humana a las necesidades de esta "persona" debe ser manejada por medio de intervenciones médicas cooperativas pero particularmente por la especialidad de enfermería. El Modelo Bifocal de Práctica Clínica de Carpenito-Moyet es una base solida en la UCIN donde los enfermeros disfrutan de la autonomía y de la cooperación cercana con los médicos y otros profesionales del cuidado de la salud (dietistas, fisioterapeutas, psicólogos).

Organizar un equipo de trabajo para un programa integral de enfermería en el contexto de un servicio de cuidado intensivo neonatal complejo requiere el uso de un marco de trabajo operativo y estructurado que ofrezca un lenguaje estandarizado. El abordaje de enfermería propuesto, de este modo, se articula con los diagnósticos de enfermería NANDA-I estandarizados correlacionados con los resultados esperados y con las intervenciones prioritarias estandarizadas (Clasificación de Intervenciones de Enfermería y Clasificación de Resultados de Enfermería) a través de los patrones funcionales de salud de Gordon y el marco conceptual de Carpenito-Moyet. Este método de diagnosticar y tratar las respuestas humanas a los problemas de salud/procesos vitales es pertinente para la unidad compuesta por el recién nacido y sus padres (la persona entera cuidada en la UCIN).

\section{SUMMARY}

- The critically ill newborn patient in the neonatal intensive care unit (NICU) provides a difficult and emotionally tough challenge for nurses. The complexity involved makes a multidisciplinary, multi-professional and multi-dimensional approach crucial. This is due to the fact that the 'person' receiving care is actually a unit composed of the newborn plus parents and therefore requires a holistic view widened out to encompass both the expressed and unexpressed needs of the family.

- The human response to the emerging health needs of this 'person' must be managed through cooperative medical interventions but especially through nursing. The Bifocal Clinical Practice Model of Carpenito-Moyet is a sound basis in the NICU where nurses enjoy both broad autonomy in providing interventions and close cooperation with doctors and the other healthcare professionals (dieticians, physiotherapists, psychologists).

- Organising smooth teamwork for an overall nursing programme in the context of a complex neonatal intensive care setting calls for the use of highly structured operative frameworks which offer a standardised language. The proposed nursing approach thus hinges upon the standardised NANDA-I nursing diagnoses aimed at correlation with expected outcomes along with standardised prioritised interventions [Nursing Interventions Classification (NIC) and Nursing Outcomes Classification (NOC)] through Gordon's functional health patterns and Carpenito-Moyet's conceptual framework. This method of diagnosing and treating the human responses to health problems/vital processes is pertinent to the unit composed of the newborn plus parents (the whole person cared for in the NICU).

\section{PREFACE}

Regarding this article and their daily clinical care and organisational practice, the authors are inspired by Carpenito-Moyet's Bifocal Clinical Practice Model (Carpenito-Moyet, 2004) and Gordon's Functional health patterns (Gordon, 2009). The application of the theory to daily practice arises from the need to pursue enhanced levels of "professional awareness" (Ramacciati, 2004) and to embody conceptual frameworks and ethical values consistently in a professional manner while providing care at the bedside. This is what Marriner-Tomey and Alligood (2007) meant by theory-based nursing practice. 


\section{* The neonatal surgical intensive care unit: a Bifocal Clinical Practice Model}

approach *

\section{BACKGROUND}

\section{Multi-professional}

Care in the NICU is one of the most stimulating and fertile areas of nursing. It is the very object of care, the person, who requires maximum commitment from all the health care professionals involved. The newborn infant who is in a critical condition, due to his/her intrinsic fragility, is a highly complex patient. Their fragility is often connected with the co-existence of severe multi-organ deficits, especially if the child is premature (i.e. a weight of less than 1500 grammes and a gestational age at birth of less than 32 weeks) and even more so if the child is very premature (i.e. a weight of less than 1000 grammes and a gestational age at birth of less than 28 weeks) or extremely premature (i.e. a weight of less than 750 grammes and a gestational age at birth of less than 25 weeks). Silverman (2003) stated, "This complexity, associated with an expanding array of therapeutic options, necessitates a multidisciplinary approach." Also, according to Hansen and Puder (2003): "to maximise the chances of a successful outcome, intensivists, surgeons, pediatric subspecialists, nurses, respiratory therapists, and dieticians (to name a few) must use their collective expertise."

\section{Multi-dimensionality}

The concept of multi-dimensionality must be added to the multidisciplinary, multi-professional nature of the approach (Ramacciati, 2008). The NICU must be 'open'. In fact the 'person' being cared for is a unit composed of newborn plus parents or, the 'newbornmother-father triad'. Thus the advanced and intensive technical interventions involved in critical area nursing must be accompanied by both counselling abilities as well as skilled communication and teaching abilities. Whereas the nursing interventions for the critically ill newborn infant are aimed at resuscitating, stabilising and sustaining basic vital functions, the interaction with the parents (especially the mother) is aimed at delivering psychological support, facilitating relationships and emotional interaction. It is not hard to imagine how devastating and dramatic it can be for a parent (or other relative) to have a newborn baby in the NICU and what scars such an experience can leave. Furthermore the almost constant presence of the parents beside the baby is of crucial importance in facilitating the progress of the newborn baby, in improving outcomes and finally in improving the quality of life of both the child whom the baby will become and the family as a whole.

\section{The surgical newborn baby}

This is the term used to describe the newborn baby with major congenital malformations who requires surgical treatment. These newborn babies, according to data taken from the international literature, represent $3 \%$ of all live born babies and are responsible for $22 \%$ of all neonatal deaths (Merenstein \& Gardner, 2006). Newborn babies with these major congenital malformations alone represent just under one third of the admissions to the NICU $(27 \%)$ and they account for about $32 \%$ of hospital days and $40 \%$ of the total costs of care (Lindower, 2006).

The surgical newborn baby, due to its clinical condition, normally requires care and stabilising medication along with complex nursing interventions over the 48 hours which precede and follow surgery, as well as assisted ventilation. Additionally they may require interventions (which may be necessary for many days or weeks) such as: total parenteral nutrition, management of (frequent) potential stomas (tracheal, oesophageal, stomach, ileum, colon, kidney) and/ or drainage (thoracic, peritoneal), and intravenous fluid intake.

In the case of the clinical conditions that require stabilisation and complex care, the surgical newborn baby needs Intensive Care (so called Level 1 or Level A according to the two main scales used for measuring the required level of neonatal care in the NICU) (Northern Neonatal Network, 1993; British Association of Perinatal Medicine, 2005), whereas for other interventions, the baby requires high dependency care (Level 2 or Level B). The Dependency Level Scales (Yoxall et al., 2001) allow for calculation of appropriate staff ratios (ratio of nurses to neonatal patients) and the prediction of nursing workloads. This makes it possible to programme, organise and manage the necessary human resources in such a way as to deliver quantitatively appropriate, high quality care (Spence et al., 2006). If we consider that the most recent scientific studies in this area call for higher staff ratios than those currently applied (1:1 for intensive care instead of the present 1:2 and 1:2 instead of the present 1:3 for high dependency care), the workload expected of the NICU nursing team is clear.

Problems of concern to the team and main nursing diagnoses for the surgical newborn baby

In such a difficult and complex context, Carpenito's Bifocal Model proves to be a useful tool for clinical practice as well as for clearly outlining the nurse's two main areas of competence, namely the role as an autonomous professional and the role as part of a team cooperating with other professionals. The nurse's specific sphere of competence consists of the diagnosis and treatment of human responses to actual or potential health problems (American Nurses Association, 1985) while the nurse, in the cooperative role, monitors the onset or variations of specific clinical conditions, following precise instructions normally issued by a doctor.

Problems of concern to the team, expressed as potential complications, which the NICU nurse frequently manages under strict medical supervision (Wilkinson, 2005) when providing care for a newborn baby with surgical problems are shown in Table 1 .

The problems of concern to the team are all centred around possible complications linked to pathologies and usually call for a nursing

Surgery: wound dehiscence, evisceration, formation of a fistula, haemorrhage, paralytic ileus, peritonitis, pulmonary embolism, kidney failure, urinary retention, thrombophlebitis General anaesthesia: stasis pneumonia, hypothermia Neck: airway obstruction, aspiration, fistula formation, haemorrhage, infection, tracheal stenosis

Eye surgery: bleeding, infection, retinal detachment Urostomy/nephrostomy: stoma necrosis, stenosis, obstruction.

Premature babies: acidosis, apnea, bradycardia, cold stress, hyperbilirubinaemia, hypocalcaemia, hypoglycaemia pneumonia, respiratory distress syndrome, convulsions, sepsis, apnea, stress cooling.

Intrauterine infections: anaemia, congenital heart diseases, deafness, hepatosplenomegaly, hydrocephalus, hyperbilirubinaemia, sepsis, disseminated intravascular coagulopathy, seizures.

Small for gestational age babies: aspiration syndrome, hypocalcaemia, hypoglycaemia, hypothermia, perinatal asphyxia, polycythaemia.

Adaptation to extra-uterine life: bleeding, cold stress, haemorrhagic diseases of the newborn, hyperbilirubinaemia, hypoglycaemia, meconium aspiration pneumonia. 


\section{* The neonatal surgical intensive care unit: a Bifocal Clinical Practice Model approach *}

response consisting of observation and monitoring, as well as interventions needed according to specific medical instructions. Nursing diagnosis, on the other hand, describes the response of the newborn to health problems linked to deficient vital functions/ processes. Nursing diagnoses can identify the psychological and social states frequently experienced by the parents of surgical newborns (the other half of the 'newborn plus parents' unit).

The most frequent adverse responses of the newborn in a critical condition who has undergone major surgery are stated in Table 2 and adverse responses of the parents of a surgical newborn are presented in Table 3.

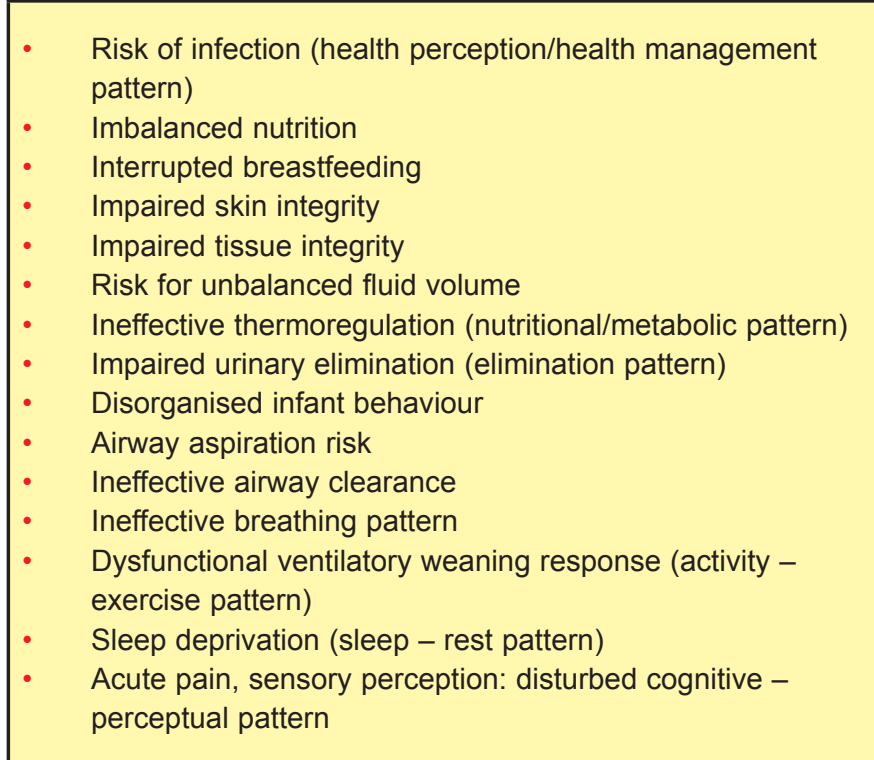

Table 2. Adverse responses of the neonate (after Gordon, 2009)

\begin{tabular}{|ll|}
\hline- & Risk for impaired parenting \\
- & Anxiety \\
- & Gear \\
- & Complicated grieving \\
- & Risk of impaired parent/child attachment \\
- & Ineffective therapeutic regimen management \\
- & Compromised family coping (self-perception/self-concept; \\
& role-relationship; coping/stress tolerance; value-belief) \\
\hline
\end{tabular}

Table 3. Adverse responses of the parents

\section{CONCLUSIONS}

Despite the scarcity of publications describing the experience of neonatal nurses in the application and study of the diagnoses (Jensen, 1990; Carrion et al., 1997; Nougueira do Vale et al., 2005; Vale, 1999; Vieira \& Rossi, 2000) and in order to plan and implement an overall nursing programme for the surgical newborn and their parents correctly and consistently, it is vital to start with a phase of careful analysis (data collection) and nursing diagnosis (identification of the human response to the health problem; their 'needs'). This is accomplished by establishing the objectives and expected outcomes through planned, specific interventions and by verifying the achievement of the final health objectives.
The overall nursing programme may be structured using standardised language both in the diagnostic phase, using the North American Nursing Diagnosis Association (NANDA) international nursing diagnoses (taxonomy II) (NANDA-I, 2009) and in the establishment of objectives and expected outcomes. The use of standardised language may also usefully apply to the phase of planning and accomplishment of interventions, Nursing Outcomes Classification (Moorhead et al., 2007) and Nursing Interventions Classification (Dochterman \& Bulecheck, 2004) of the lowa Nursing Project. Furthermore, this programme can be facilitated by the implementation and adaptation of linkages between diagnosis objectives - interventions as proposed by recent studies (Johnson et al., 2006).

\section{REFERENCES}

American Nurses Association (1985). Nursing: A Social Policy Statement. Washington: American Nurses Association.

British Association of Perinatal Medicine (2001). Standards for hospitals providing neonatal intensive and high dependency care. Categories of babies requiring neonatal care. 2nd ed. London: British Association of Perinatal Medicine.

Carpenito-Moyet LJ (2004). Diagnosi infermieristiche Applicazione alla pratica clinica. $2 a$ ed. Milano, Italy: Casa Editrice Ambrosiana.

Carrion PG, Garcia RS, Castillo J, Ruiz PA, Ruiz AP (1997). NANDA Nursing diagnoses identification and validation in a neonatal unit. Pediatric Nursing 23, 351-358.

Dochterman J, Bulecheck H (2004). Nursing interventions classification (NIC). 5th ed. St. Louis, MO: Mosby.

Ferens $S$ (2002). La cartella infermieristica in ambito maternoinfantile. Una proposta per la didattica clinica secondo i modelli di Carpenito e Gordon. Nursing Oggi 3, 70-76.

Gordon M (2009). Diagnosi infermieristiche Processo e applicazione. Milano, Italy: Casa Editrice Ambrosiana.

Hansen AR, Puder M (2003). Neonatal Surgical Intensive Care. Hamilton, Canada: BC Decker.

Jensen DJH (1990). The applicability of nursing diagnoses in the neonatal intensive care unit. Neonatal Network 9(2), 25-29.

Johnson J, Bulecheck G, Butcher H, Maas M, McCloskey Dochterman J, Moorhead S, Swanson L (2006). NANDA, NOC, and NIC linkages: Nursing Diagnoses, outcomes, \& interventions. 2nd edition. St Louis, MO: Mosby.

Lindower J, Atherton H, Kotagal U (1999). Outcomes and resource utilization for newborns with major congenital malformations: the initial NICU admission. Journal of Perinatology 19, 212-215.

Marriner-Tomey A, Alligood MR (2007). La teoria del nursing. Milano (Italy): McGraw-Hill.

Merenstein GB, Gardner SL (2006). Neonatal Intensive Care. 6th ed. St. Louis, MO: Mosby.

Moorhead S, Johnson M, Maas ML, Swanson E (2007). Nursing Outcomes Classification (NOC), 4th edition. St. Louis, MO: Mosby.

NANDA-I (2009). Diagnosi infermieristiche Definizioni e classificazione 2009-2011. Milano (Italy): Casa Editrice Ambrosiana.

Nogueira do Vale I, Regina de Sauza S, Carmona EV (2005). Nursing diagnoses identified during parent group meetings in a neonatal intensive care unit. International Journal of Nursing Terminology and Classification 3-4(16), 65-73. 
Northern Neonatal Network (1993). Measuring neonatal nursing workload, Archives of Diseases in Childhood 68, 539-543.-879.

Ramacciati N (2004) Nuove strategie di gestione dell'operatività infermieristica. Nursing Up Magazine 1(1), 10-12.

Ramacciati N (2008). II neonato chirurgico, complessità assistenziale e approccio bifocale. Professione Infermiere Umbria 10(2), 28-31.

Spence K, Tarnow-Mordi W, Duncan G, Jayasuryia N, Elliott J, King J, Kite $F$ (2006). Measuring nursing workload in neonatal intensive care. Journal of Nursing Management 14, 227-234.

Silverman GA, Shamberger RC (2003). Foreword, In: Hansen AR, Puder M, Neonatal Surgical Intensive Care. Hamilton, Canada: BC Decker.
Vale IN (1999). Risk for ineffective breastfeeding: a definition for nursing diagnosis, São Paulo, Brazil: Tese, Escola de Enfermagem, Universidade de São Paulo.

Vieira CS, Rossi LA (2000). NANDA nursing diagnoses in mothers with a hospitalized preterm child in an NICU, Revista LatinoAmericana de Enfermagem 8, 110-116.

Wilkinson JM (2005). Diagnosi infermieristiche con NOC e NIC Milano, Italy: Casa Editrice Ambrosiana.

Yoxall CW, Cooke RWI, Shaw NJ, Subhedar NV, Weindling AM (2001). Dependency level of babies on the neonatal unit: a comparison of two different classification systems. Archives of Diseases in Childhood 85, F173-F176. 